\title{
Political Trust and the Success of Fiscal Consolidation: Lessons from Sweden and Hungary
}

by Dóra Győrffy

In spite of early expectations, the liberalisation of capital markets did not induce a worldwide improvement in fiscal balances. Interpreting fiscal adjustment as a form of social dilemma, the article addresses this puzzle through considering the consequences of political trust on the success of consolidations. Based on a comparative analysis of Swedish and Hungarian fiscal reforms during the mid-1990s, it is shown that the level of trust strongly affects both the method of implementation and the composition of the stabilisation package, which in turn determine the long-term sustainability of the adjustment. Evidence from Economic and Monetary Union indicates the potential for generalising these findings and support the claim that lasting fiscal consolidations can be expected only in a high-trust environment. In a low-trust regime, even if external pressures trigger adjustment, the incentive to buy support through short-term promises ultimately erodes the commitment to restraint and imbalances re-emerge. ${ }^{1}$

Entgegen den ursprünglichen Erwartungen führte die Liberalisierung der Kapitalmärkte nicht zu einem weltweit verbesserten Gleichgewicht der öffentlichen Haushalte. Dieser Beitrag interpretiert fiskalische Anpassungsmaßnahmen als soziales Dilemma und untersucht auf dieser Grundlage die Auswirkungen von politischem Vertrauen auf den Erfolg von Konsolidierungspolitiken. Anhand einer vergleichenden Analyse der Reformen in Schweden und Ungarn Mitte der 1990er Jahre wird aufgezeigt, dass das Ausmaß des Vertrauens einen starken Einfluss sowohl auf die Art der Implementation als auch auf die Zusammensetzung der Stabilisierungsmaßnahmen hat, wovon wiederum die Nachhaltigkeit der Anpassung abhängt. Daten aus den Mitgliedstaaten der Europäischen Wirtschafts- und Währungsunion deuten darauf hin, dass diese Erkenntnisse grundsätzlich generalisierbar sind, und stützen die These, dass anhaltende fiskalische Konsolidierung nur unter der Bedingung hohen politischen Vertrauens zu erwarten ist. Anderenfalls erodieren auch unter externem Konsolidierungsdruck die entsprechenden Anstrengungen durch den Anreiz, über kurzfristige Versprechungen öffentliche Unterstützung zu erhalten.

1 The contribution is based on research conducted at the Central European University, Budapest. I am indebted to László Csaba for his constant support and encouragement. I am also grateful to Péter Gedeon and László Muraközy for helpful comments on an earlier version of this article. 


\section{Introduction}

At the beginning of the 1990s, there was a strong expectation that globalisation implies the loss of state autonomy, the collapse of the welfare state and a general macroeconomic convergence across the world. ${ }^{2}$ Today there is little debate among social scientists that this strong version of convergence was a premature prediction. We do not observe a race to the bottom in labour or environmental standards, taxation of capital increased rather than decreased and the examples of Scandinavian countries show that welfare states can be competitive in this new environment. ${ }^{3}$ With the exception of inflation, which has indeed declined, ${ }^{4}$ even macroeconomic policies appear to defy the conventional wisdom: Garrett as well as Tytell and $\mathrm{Wei}$ failed to find any significant correlation between openness and budget deficit. ${ }^{5}$ While it can be argued that the welfare state provides public goods, which are beneficial to competitiveness, even Keynesian economics do not endorse sustained budget deficits and there is considerable empirical evidence that they are harmful to economic growth. ${ }^{6}$ Consequently the question arises why we fail to see a declining trend in budget deficits in spite of the pressures from the international capital markets and a normative consensus about the importance of fiscal balance.

The difficulties with the long-term consolidation of public finances are not due to the lack of international evidence about which measures work and which do not. Mainstream economic thinking today attributes the success and sustainability of fiscal consolidations to their composition. Due to gains in policy credibility, adjustments, which cut politically sensitive expenditure such as government wages and social transfers, are more likely to be lasting than consolidations,

2 See e.g. Cerny, P.G.: The Dynamics of Financial Globalization: Technology, Market Structure and Policy Response, in: Policy Sciences, 27/4 (1994), 319-342; Strange, S.: The Retreat of the State: Diffusion of Power in the World Economy, Cambridge/New York, 1996.

3 Geyer, R. R.: Globalization, Europeanization, Complexity and the Future of Scandinavian Exceptionalism, in: Governance, 16/4 (2003), 559-576; Weiss, L.: States in the Global Economy: Bringing Domestic Institutions Back In, Cambridge 2003.

4 Rogoff, K.: Globalization and Global Disinflation, in: Federal Reserve Bank of Kansas City Economic Review, 88/4 (2003), 45-78.

5 Garrett, G.: Global Markets and National Politics: Collision Course or Virtuous Circle?, in: International Organization, 52/4 (1998), 787-824; Tytell, I./Wei, S.-J.: Does Financial Globalization Induce Better Macroeconomic Policies?, IMF Working Paper no. 04/84, 2004.

6 Adam, C.S./Bevan, D.L.: Fiscal Deficits and Growth in Developing Countries, in: Journal of Public Economics, 89/4 (2005), 571-597. 
which rely on revenue increase and cuts in public investment. ${ }^{7}$ Besides the composition of the adjustment, economists have also emphasised the importance of rules governing the budget process as useful tools to resolve the common pool resource dilemma of fiscal policy, when particular constituencies internalise the full benefit of extra spending but pay only a fraction of the social cost. ${ }^{8}$

The persistence of divergence, in spite of a widespread agreement on the need and methods of achieving fiscal balance, makes the issue of fiscal consolidation an excellent field to analyse the domestic factors, which determine whether a country adapts to global pressures or not. In order to solve the problem two specific questions need to be answered. What drives governments' choice about the method of fiscal consolidation? Under what conditions are international best practices implemented?

This contribution examines the contrasting cases of Sweden and Hungary. In the mid-1990s they both faced a serious crisis, which made fiscal adjustment imperative. Although the problems had very different roots in the two cases, the symptoms were strikingly similar and parallel in time: in the early 1990s, both countries registered a sharp decline in output, systemic crisis in the banking sector, high level of unemployment and large fiscal imbalances. During the mid-1990s they followed different paths in adjusting their public finances: Sweden implemented structural reforms and strengthened the framework for budgetary decision-making, while Hungary turned to inflationary financing and relied on shortterm measures to raise revenue. A decade later the outcome reflects the different methods: while consolidation proved to be sustainable in Sweden, imbalances reemerged in Hungary. The contrasting experiences of the two countries are far from self-evident as they share a number of important similarities. They are both small, open economies, which implies an important role for the disciplinary forces of the international financial markets. State redistribution is traditionally high in both countries. In both cases fiscal crisis was managed by left-wing governments. If we assume that international experiences about best solutions were

7 Alesina, A./Perotti, R.: Fiscal Adjustments in OECD Countries: Composition and Macroeconomic Effects, NBER Working Paper no. 5730, Cambridge, MA, 1996; Alesina, A./Perotti, R./Tavares, J.: The Political Economy of Fiscal Adjustments, in: Brookings Papers on Economic Activity 1/1998, 197-266; Ardagna, S.: Fiscal Stabilizations: When Do They Work and Why, in: European Economic Review, 48/5 (2004), 1047-1074.

8 Perotti, R./Strauch, R./Hagen, J.v.: Sustainability of Public Finances, London, 1998; Poterba, J.M./Hagen, J.v. (eds.): Fiscal Institutions and Fiscal Performance, Chicago/London, 1999; Hagen, J.v.: Budgeting Procedures and Fiscal Performance in the EC, European Economy - Economic Papers no. 96, Brussels, 1992. 
equally available to them, we have to consider domestic political factors to explain why they chose different solutions to a very similar problem.

Looking at fiscal adjustments as typical social dilemma situations, this contribution aims to address the above puzzle through considering the effects of political trust on consolidations. According to Bo Rothstein, ${ }^{9}$ social dilemmas are situations when individual and collective rationality comes into conflict. In the field of fiscal policy, this means that although society as a whole has an interest in the sustainability of public finances, individuals would not like to be among those, who bear the costs of consolidation. In such situations, trust in the system becomes critical. Examining the implications of these ideas in the Swedish and Hungarian cases, the main thesis of the paper is that in the absence of strong external pressures, long-term consolidation of public finances can be achieved only in a high-trust regime. In a low-trust environment even if an external shock triggers adjustment budgetary imbalances are likely to re-emerge given the incentives of politicians to continuously buy support through short-term spending. This incentive strongly reduces the possibility of consensus on necessary institutional reforms as well as the demand for implementing international best practices.

The argument proceeds in three steps. The next section analyses the main channels through which political trust can affect fiscal policy and the success of consolidations. Afterwards, the economic crisis and adjustment is described in the cases of Sweden and Hungary followed by a theory-driven comparison about the politics of consolidation. The third part of the paper considers the potential for generalising the findings through considering the experiences of the member states of the Economic and Monetary Union (EMU) between 1998 and 2005. The final section discusses the main implications of the research.

\section{Political Trust and Fiscal Balance}

The most general understanding of political trust is that it is "the belief that the political system will produce 'good' outcomes" 10 . For the citizen, good outcomes mean an improvement in her well-being. This view considers trust as a rational response to past institutional performance. While a different trend of the litera-

9 Rothstein, B.: Just Institutions Matter: the Moral and Political Logic of the Universal Welfare State, Cambridge, 1998.

10 Anderson, C.J. et al.: Losers' Consent: Elections and Democratic Legitimacy, Oxford, 2005, 19. 
ture assigns a key role to deep-seated cultural beliefs and interpersonal trust in explaining trust in institutions, ${ }^{11}$ in the post-communist region it has been shown that political and economic performance is a better predictor of political trust than cultural factors. ${ }^{12}$ The two explanations however are not necessarily contradictory: as trust is hard to establish and hard to change, the collective memory about past institutional performance is a key variable explaining different level of political trust across countries. ${ }^{13}$ The considerable debate over the origins of political trust reflects its enormous significance for democratic systems. Trust enables the government to rely on the cooperative behaviour of the citizens without the need for coercion and thus enhances its potential for effective action. ${ }^{14}$

Trust is especially important in cases, where citizens are asked to make material sacrifices. ${ }^{15}$ Fiscal policy is clearly such an area as recognised by studies on tax compliance. The most important puzzle in this field is that tax payers are considerably more honest than it could be expected based on the probability of punishment for cheating. ${ }^{16}$ A number of empirical studies indicate that trust might be the solution to this puzzle. John Scholtz and Mark Lubell showed that trustworthy institutions and trust in other citizens' honesty increases tax compliance even after controlling for fear of punishment and a perceived duty to obey tax laws. ${ }^{17}$ A similar argument is made by Junko Kato and Bo Rothstein claiming that people in Sweden are willing to pay high taxes because they see that they receive substantial benefits in return allocated through fair procedures. ${ }^{18}$

11 Almond, G. A./Verba, S.: The Civic Culture: Political Attitudes and Democracy in Five Nations, Princeton, NJ, 1963; Inglehart, R.: The Renaissance of Political Culture, in: American Political Science Review, 82/4 (1988), 1203-1230; Putnam, R. D.: Making Democracy Work, Princeton, NJ, 1993.

12 Mishler, W./Rose, R.: What are the Origins of Political Trust? Testing Institutional and Cultural Theories in Post-Communist Societies, in: Comparative Political Studies, 34/1 (2001), 30-62.

13 Rothstein, B.: Trust, Social Dilemmas and Collective Memories, in: Journal of Theoretical Politics, 12/4 (2000), 477-501.

14 Gamson, W.A.: Power and Discontent, Homewood, IL, 1968, 43-45; Braithwaite, V.A./Levi, M.: Trust and Governance, New York, 1998.

15 Hetherington, M.J.: Why Trust Matters: Declining Political Trust and the Demise of American Liberalism, Princeton, NJ, 2004; Rudolph, T.J./Evans, J.: Political Trust, Ideology, and Public Support for Government Spending, in: American Journal of Political Science, 49/3 (2005), 660-671.

16 Andreoni, J./Erard, B./Feinstein, J.: Tax Compliance, in: Journal of Economic Literature, 36/2 (1998), 818-860, here 822 .

17 Scholtz, J.T./Lubell, M.: Trust and Tax-paying: Testing the Heuristic Approach to Collective Action, in: American Journal of Political Science, 42/2 (1998), 398-417.

18 Kato, J./Rothstein, B.: Government Partisanship and Managing the Economy: Japan and Sweden in Comparative Perspective, in: Governance, 19/1 (2006), 75-97, here 86. 
While the revenue side of fiscal policy has received considerable attention in the literature on the effects of trust, the expenditure side has been somewhat neglected. Although the potential to raise revenue strongly conditions the potential to spend, it is also necessary to consider pressures for spending without corresponding revenues. This is particularly important in countries where citizens are not perfectly informed about the long-term consequences of government expenditures. Bounded rationality towards fiscal decisions have been first theorised by James Buchanan and Richard Wagner in the concept of fiscal illusion, ${ }^{19}$ which means that voters overvalue current benefits while discount future taxes. The presence of this illusion allows the governments to use fiscal policy as a tool to enhance their support through increasing benefits or cutting taxes. One consequence of this possibility is the tendency to use anticyclical fiscal policy asymmetrically - while governments spend more during downturns, they do not accumulate corresponding surpluses during economic upturns. Recent research has confirmed this hypothesis empirically. Fabrizio Balassone and Maura Francese showed that asymmetrical stabilisation is the rule rather than the exception even in the OECD countries, where citizens are likely to be better informed about government policy and its consequences than in developing countries. ${ }^{20}$

The possibility to use fiscal policy for enhancing political support has farreaching consequences for the expenditure-side of the budget in a low-trust regime. If the citizens do not believe that the system produces good outcomes then they are less willing to face temporary hardship. Consequently, the government has to coerce them to comply with its demands or buy their support through short-term benefits. Since the potential to use coercion is limited in a democratic setting, governments are likely to choose the latter option, which gives the expenditure side of fiscal policy a privileged role. In an environment where political support can be gained only through short-term spending, a prisoners' dilemma emerges before elections (Figure 1). While the long-term interest of the country would require responsible fiscal policy, the dominant strategy for both the government and the opposition is making short-term promises and excess

19 Buchanan, J.M./Wagner, R.E.: Democracy in Deficit: the Political Legacy of Lord Keynes, San Diego, CA/London, 1977.

20 Balassone, F./Francese, M.: Cyclical Asymmetry in Fiscal Policy, Debt Accumulation and the Treaty of Maastricht, Banca d'Italia Working Paper no. 531, 2004. 
spending. This problem can be particularly acute in new democracies, where the electorate has yet to learn that such spending comes at a cost in the long-run. ${ }^{21}$

Figure 1: Prisoners' Dilemma during Elections in a Low-trust Regime

\begin{tabular}{|c|c||c|c|}
\hline \multicolumn{2}{|c||}{} & \multicolumn{2}{c|}{ Government } \\
\cline { 3 - 4 } \multicolumn{2}{|c||}{} & Election spending & $\begin{array}{c}\text { Responsible } \\
\text { fiscal policy }\end{array}$ \\
\hline \hline \multirow{3}{*}{ Opposition } & $\begin{array}{c}\text { Overspending } \\
\text { promises }\end{array}$ & $\begin{array}{c}\text { Uncertain } \\
\text { election outcome }\end{array}$ & $\begin{array}{c}\text { Opposition wins } \\
\text { the election }\end{array}$ \\
\cline { 2 - 4 } & $\begin{array}{c}\text { Responsible } \\
\text { campaign }\end{array}$ & $\begin{array}{c}\text { Government wins } \\
\text { the election }\end{array}$ & $\begin{array}{c}\text { Uncertain } \\
\text { election outcome }\end{array}$ \\
\hline
\end{tabular}

Source: Author's compilation.

The prisoners' dilemma situation is not impossible to solve however. If the two opposing parties can come to a consensus on the necessity of long-term fiscal restraint it might be possible to undertake measures which are conducive to longterm sustainability. At the same time, lack of trust in the political system makes such a consensus difficult.

The first potential channel from political trust to lack of consensus is the iterated nature of the prisoners' dilemma situation. If the actors have gone through numerous rounds of the game and defection was the characteristic strategy, then lack of trust in the political system can lead to the deterioration of trust within the political elite. The absence of trust within the elite makes consensus on selfrestraint unlikely and it becomes more and more difficult to solve the prisoners' dilemma.

A second potential channel from political trust to elite polarisation is the perceived need for taking confrontational positions in the policy debate. If the public is disillusioned from the political system it often implies that this disillusionment refers not only to the ruling government but to the elite in general including their own party or union leaders. Such distrust can have important consequences for the strategies of the elite. In order to gain support politicians need to articu-

21 The difference between old and new democracies in terms of election spending has been shown by Brender and Drazen, who found that election cycles are mostly a characteristic of developing countries (Brender, A./Drazen, A.: Political Budget Cycles in New versus Established Democracies, NBER Working Paper no. 10539, Cambridge, MA, 2005). 
late positions in line with the perceived short-term interests of their potential voters. If they agree to short-term sacrifices and compromise for the sake of a consensus with the rival parties, they might be easily seen as betraying the interests of their voters. Consequently confrontation rather than cooperation becomes the norm. In contrast in a high-trust regime, where long-term gains for short-term sacrifices are seen as credible, compromises are more likely to be accepted and cooperation within the elite is more likely to emerge.

In an environment, which is characterised by populist tendencies and a confrontational political culture, the demand for international best practices is likely to be lower than in a high-trust regime. Given the need to buy votes through shortterm promises, governments are unlikely to limit their discretion over the use of public money and introduce self-binding mechanisms. This becomes even less likely if the trust within the elite has been eroded through numerous rounds of the prisoners' dilemma game: unilateral self-binding is not a rational strategy if the government cannot be sure that the opposition will respect the new rules.

The relationship between political trust and fiscal policy pressures implies that, in the absence of external forces, long-term fiscal balance can be expected only in a high-trust environment. This does not mean that only high-trust regimes can have fiscal balance. There are a variety of international pressures, which can force governments to consolidate their finances. A financial crisis or the conditions attached to joining the Economic and Monetary Union (EMU) might lead to the balancing of public finances. The theoretical claim presented here implies that once these pressures are gone imbalances are likely to re-emerge in low-trust regimes due to pressures on both the revenue and the expenditure sides of the budget. The next section illustrates this argument through the comparative analysis of fiscal consolidation in Sweden and Hungary during the mid-1990s.

\section{Fiscal Consolidation in Sweden and Hungary}

At first sight, Sweden and Hungary appear an unlikely pair for comparison. In spite of the similarities noted in the introduction, there are a number of differences which might account for their different fiscal performance. The most evident difference is their level of development: while Sweden is one of the most advanced countries in the world, Hungary is a transition country, which is a long way from catching up with its Western neighbours. This alone however cannot account for their contrasting fiscal performance, because before the adjustment large deficits were far from unusual in either case, which is indicated by the 
considerable public debt both countries had during the mid-1990s. ${ }^{22}$ A second important difference between the two countries concerns labour market relations. Sweden is regularly cited as a model for corporatism, which can make social consensus on fiscal adjustment considerably easier than in countries like Hungary, where there are no such inclusive interest groups. Two arguments can be made against this claim. First, the cooperation between labour and capital, which lay behind the success of the Swedish model until the 1970s, showed considerable signs of erosion by the 1990s making it more difficult to arrive to consensus on major issues. ${ }^{23}$ Second, given the general weakness of trade unions in transition countries, ${ }^{24}$ they are unlikely to present considerable obstacle to consensus and fiscal adjustment. The third difference between the cases is that Hungary aims to join the EMU, while Sweden has been postponing accession due to the public resistance of giving up their national currency. ${ }^{25}$ Conventional wisdom would suggest that under these circumstances it would be Hungary which follows more responsible fiscal policies. The opposite outcome makes the comparison especially interesting if we are interested in how external pressures influence domestic policy.

The fourth difference between the two countries is the different degree of trust, which is claimed to be the crucial factor in the success of fiscal consolidation. On this dimension, the two countries are as far apart as they are on their fiscal performance. Sweden performs considerably better on every indicator, which is generally associated with trust in the system. Institutional satisfaction is signalled by the general support for the universal welfare in spite of the high level of taxes

22 In 1996, shortly after a consolidation package was implemented in both countries, debt level in Hungary was $71.7 \%$ while $73 \%$ in Sweden (European Commission: Statistical Annex of European Economy: Autumn 2006, Brussels, 2006, 181).

23 Pontusson, J./Swenson, P.: Labor Markets, Production Strategies, and Wage Bargaining Institutions: the Swedish Employer Offensive in Comparative Perspective, in: Comparative Political Studies, 29/2 (1996), 223-250; Martin, A.: The Politics of Macroeconomic Policies and Wage Negotiations in Sweden, in: Iversen, T./Pontusson, J./Soskice, D. (eds.): Unions, Employers and Central Banks: Macroeconomic Coordination and Institutional Change in Social Market Economies, Cambridge/New York, 2000, $232-264$.

24 Ost, D.: Illusory Corporatism in Eastern Europe: Neoliberal Tripartism and Postcommunist Class Identities, in: Politics and Society, 28/4 (2000), 503-530.

25 Unlike the United Kingdom and Denmark, Sweden does not have an opt-out from the common currency, which means that it is obligated to introduce the euro eventually. It stays out of the EMU through not fulfilling the exchange-rate criterion. On the reasons for the public resistance to joining see Jonung, L.: The Political Economy of Monetary Unification: the Swedish Euro Referendum of 2003, in: CATO Journal, 24/1-2 (2003), 123-149. 
it entails ${ }^{26}$ as well as by the low level of corruption perceptions. ${ }^{27}$ In contrast, in Hungary a large majority of the population (steadily around 70 percent) feels that it was better during the previous regime ${ }^{28}$ while perceptions about corruption signal serious institutional weaknesses. ${ }^{29}$ Life satisfaction, which cultural theories consider a crucial determinant of political trust ${ }^{30}$ is also considerably higher in Sweden than in Hungary: based on a ten-point scale, where ten signals the highest level of satisfaction, the average in Sweden has been over 7.5 since 1990, while it has been around six in Hungary. ${ }^{31}$ On the basis of these factors, it is reasonable to conclude that any way it is defined, political trust in Sweden is significantly higher than in Hungary. In order to show that this is the critical difference which accounts for their divergent fiscal performance, the next two sections provide an overview about how the two countries dealt with an economy-wide crisis during the mid-1990s. This is followed by a comparative analysis focusing on the role of trust in explaining the different policy choices.

\section{Financial Crisis and Adjustment in Sweden}

At the beginning of the 1990s, Sweden entered into a period of deep recession. There were several reasons behind, which together were responsible for the economic downturn.

The most important factor was the deregulation of the financial sector during the 1980s, which was expected to increase competition and efficiency in the capital markets. In the short-term however, these competitive pressures led to a greater willingness on the part of banks to face considerable risks in order to raise their profit. Such behaviour was also motivated by the shared assumption that the

26 Rothstein, B.: Just Institutions Matter, op. cit., 167; Timonen, V.: What Explains Public Sector Restructuring? Evaluating Contending Explanations, in: Journal of European Public Policy, 8/1 (2001), 43-59.

27 Sweden is steadily among the six least corrupt countries in the world according to the measures of Transparency International. In the past ten years its score on the Corruption Perceptions Index (CPI) has ranged between 9 and 9.5 points on a scale of 10 . For the yearly data see the Transparency International website: http://www.transparency.org/policy_research/surveys_indices/cpi.

28 Rose, R.: Diverging Paths of Post-communist Countries: New Europe Barometer Trends since 1991, Studies in Public Policy no. 418, Centre for the Study of Public Policy, Glasgow, 2006, $37 \mathrm{f}$.

29 According to Transparency International, the CPI scores for Hungary ranged between 4.8 and 5.3 in the past ten years.

30 Inglehart, $R$., op. cit.

31 Kornai, J.: The Great Transformation in Central Eastern Europe. Success or Disappointment?, in: Economics of Transition, 14/2 (2006), 207-244, here 234. 
government will not allow banks to fail. ${ }^{32}$ This led to a credit expansion, which in turn resulted in an asset boom and rising inflation. ${ }^{33}$ Households were motivated to borrow because of the tax deductibility of interest expenses for both mortgages and consumer loans. Furthermore Swedish citizens were not allowed to buy foreign shares until 1989 thus all the credit flew into the domestic economy and contributed to the overheating.

In the previous decades, full employment presented a constant challenge for maintaining price stability. The solution to this problem was centralised wage bargaining, where the export sector played a steering role in order to preserve the competitiveness of the economy. ${ }^{34}$ By the 1980 s, this method did not work anymore for two major reasons. First, with the expansion of the public sector in the 1970s, the export sector lost its leadership during the wage negotiations, which meant that the determination of wages was more driven by post-materialist values than by considerations of competitiveness. ${ }^{35}$ Second, the establishment of union-controlled wage-earners funds, which were designed to increase the unions' role in the management of the companies, undermined the cooperation between capital and labour. ${ }^{36}$ These developments culminated in the collapse of centralised collective wage negotiations in 1983: when engineering unions pushed for more wage differentiation in order to attract skilled labour, the radicalised public sector trade unions were unwilling to accommodate their needs. ${ }^{37}$ The consequence of this breakdown was the loss of income policy as a tool to avert inflationary pressures.

Rising inflation implied the overvaluation of the currency, which meant that the competitiveness of the Swedish economy declined. In the previous decades, this

32 Drees, B./Pazarbasioglu, C.: The Nordic Banking Crisis: Pitfalls in Financial Liberalization?, IMF Occasional Paper no. 161, 1998, 19.

33 Between 1986 and 1989, the ratio of bank loans to GDP increased from $40 \%$ to 58\% (Drees, B./Pazarbasioglu, C., op. cit., 19). The availability of credit led to an increase in asset prices, which was accentuated by real estate speculation resulting in an upward spiral (Svensson, T./Mabuchi, M./Kamikawa, R.: Managing the Bank-system Crisis in Coordinated Market Economies: Institutions and Blame Avoidance Strategies in Sweden and Japan, in: Governance, 19/1 (2006), 43-74, here 47). In the meantime inflation rose from $4.7 \%$ in 1986 to $9.7 \%$ by 1990 (European Commission, op. cit., 79) contributing to further price increases.

34 Edgren, G./Faxén, K.-O./Odhner, C.-E.: Wage Formation and the Economy, London, 1973.

35 Lindbeck, A.: The Swedish Experiment, in: Journal of Economic Literature, 35/3 (1997), 1273-1319, here 1282 .

36 Martin, A., op. cit., 205.

37 Swank, D.: Global Capital, Political Institutions and Policy Change in Developed Welfare States, Cambridge/New York, 2001, 136; Pontusson, J./Swenson, P., op. cit., 247. 
problem was handled through the devaluation of the currency. However, in 1987 the Swedish krona was fixed to the ECU in order to increase policy credibility. ${ }^{38}$ Monetary policy was thus not available to respond to the overheating of the economy. This situation made Sweden vulnerable to external shocks.

When the international economy entered into a recession in 1990, the declining competitiveness of Swedish products meant a sharp decline of export revenue and consequently employment. This triggered speculations about a forthcoming devaluation. The Riksbank tried to avert these pressures through sharply raising the interest rate but this step only deepened the crisis. The situation was further worsened by the effects of a poorly-timed tax reform in 1991, which aimed at lowering income tax rates, eliminating exceptions and shifting the tax burden to consumption. Together with excessive interest rates, high taxes on consumption led to a sharp increase in savings. The corresponding decline in consumption resulted in the collapse of domestic demand. As the elimination of tax exceptions mainly concerned the withdrawal of housing subsidies, the collapse of asset prices followed the collapse in demand, which strongly affected the banking sector. The overall result was the worst economic crisis since the 1930s: gross domestic product fell by $6 \%$ between 1991 and 1993, unemployment rose to $12 \% .{ }^{39}$ Given the automatic stabilisers from the extensive welfare arrangements, the level of fiscal deficits reached $12 \%$ of the GDP, while public debt surpassed $70 \%$ of the GDP. ${ }^{40}$

The first step to resolve the crisis was allowing the krona to float in November 1992. The resulting sharp devaluation halted the crisis and improved the competitiveness of the economy. The next step was the rescue of the banking system. For this purpose, the government implemented a three-pillar strategy: it guaranteed all liabilities of all banks; established an independent institution to administer the guarantees and took over the bad loans. ${ }^{41}$ The strategy was successful: in comparison to other countries, the costs of rescue were considerably smaller and the recovery faster. ${ }^{42}$

38 Kato, J./Rothstein, B., op. cit., 82-84.

39 Svensson, T./Mabuchi, M./Kamiwaka, R., op. cit., 48.

40 For a more detailed description of the crisis see Cerra, V./Saxena, S.C.: Eurosclerosis or Financial Collapse: Why Did Swedish Incomes Fall Behind?, IMF Working Paper no. 05/29, 2005.

41 Svensson, T./Mabuchi, M./Kamiwaka, R., op. cit., 48.

42 Drees, B./Pazarbasioglu, C., op. cit., 35. 
The halting of the financial crisis marked the start of economic reforms, which aimed at stabilising public finances in a lasting manner. Public debt had been rising since the mid-1970s reaching $73.2 \%$ of the GDP by $1994 .{ }^{43}$ The steadily growing debt level implied a constraint on economic policy-making and indicated that fiscal policy was not on a sustainable path. It also showed that the greatest problem was not necessarily the excessive cyclical sensitivity of the budget, which was natural given the extensive welfare arrangements, but the asymmetrical nature of this sensitivity: while there were substantial deficits during economic downturns, corresponding surpluses were not accumulated during economic upturns. ${ }^{44}$ This suggested serious institutional weaknesses in budgetary decision-making, which also needed to be remedied during the reform process.

In order to consolidate public finances, in 1995 the social democratic government implemented a package which addressed both the expenditure and the revenue side of the budget. ${ }^{45}$ Within four years, expenditure was cut by nine percentage points of the GDP. Social benefits were cut by three percentage points through the reduction of the income replacement ratio as well as the introduction of waiting days for sickness and unemployment benefits. Spending on pensions was also reduced both through short-term nominal cuts as well as through a comprehensive set of reforms which reset the base for pension calculations from the best 15 years to lifetime earnings and indexed pensions to wages rather than inflation. ${ }^{46}$ Transfers and subsidies to business were reduced by one percentage point, while public consumption and investment decreased by 1.5 percentage points. On the revenue side, with the resumption of growth, tax revenues increased contributing to the improvement of the fiscal stance by four percentage points.

To entrench the improvements in public finances and prevent the re-emergences of imbalances, budgetary regulations were redesigned in a systematic manner. The main problems of the old system were the bottom-up approach during the planning and adoption phases, a relative neglect of transparency as well as in-

43 European Commission, op. cit., 181.

44 Lindh, Y./Ohlsson, H.: Trends in Swedish Public Finances - Past and Future, in: Sveriges Riksbank Economic Review, 3/4 (2000), 83-102, here 86-91.

45 The following description of the adjustment is based on IMF: Sweden: Selected Issues, IMF Staff Country Report no. 98/124, Washington, DC, 1998.

46 For a comprehensive overview of Swedish pension reform see Anderson, K. M.: The Politics of Retrenchment in a Social Democratic Welfare State: Reform of the Swedish Pension and Unemployment Insurance, in: Comparative Political Studies, 34/9 (2001), 1063-1091, here 1076-1080. 
adequate attention to long-term developments, which allowed the dominance of interest groups during the budgetary decision-making process. ${ }^{47}$ The solution to these problems was a combination of numerical and procedural rules which strengthened the decision-making framework during all phases. ${ }^{48}$ To facilitate continued debt reduction, the government committed itself to a general budgetary surplus of two percent of the GDP over the cycle. This rule was complemented by ceilings for the individual budgetary items including all central government expenditure, local government grants as well as pensions for the next three years. Compliance with the objectives of this legally binding multi-year fiscal framework was to be strictly monitored. In the planning and adoption phases, a strong top-down framework was implemented implying that the aggregates of the budget are decided first and detailed appropriations afterwards. This method gives a strong position to the Ministry of Finance, which is responsible for aggregate spending. The transparency of the budget also improved considerably making informed decision-making easier.

The overall outcome was even better than the ambitious targets envisaged in the original programme. The improvement in government finances during the period between 1994 and 1998 was 11 percentage points of the GDP, 1.5 percentage points higher than planned, which was mainly due to the lower-than-expected interest payments. This showed the overall credibility of the adjustment: believing the government's resolve to cut deficits, investors assigned lower and lower risk premium for Swedish debt, which in turn improved performance further and reinforced positive expectations. The achievements of the package proved to be sustainable: in spite of its large level of redistribution, Sweden has a regular surplus in its budget and succeeded in cutting its debt considerably. ${ }^{49}$ The country is among the most competitive economies in the world ${ }^{50}$ while it was able to preserve the universality of its welfare provisions.

47 Molander, P.: Reforming Budgetary Institutions: the Swedish Experiences, in: Strauch, R./Hagen, J.v. (eds.): Institutions, Politics and Fiscal Policy, Dordrecht/Norwell, MA, 191-214.

48 The following overview relies on Molander, P., op. cit.

49 Sweden registered a fiscal surplus every year between 1998 and 2006 with the exception of 2002. Its public debt declined to $46.7 \%$ by 2006 (European Commission, op. cit., 177, 181).

50 See the annual surveys of the World Economic Forum at http://www.weforum.org. 


\section{Fiscal Imbalances in Hungary}

Similarly to Sweden, Hungary also faced an economy-wide crisis in the early 1990s. By 1994, the country was approaching a financial collapse: its debt totalled $88 \%$ of the GDP, while it had a current account and fiscal deficit in excess of $8 \%$ of the GDP. ${ }^{51}$ After the debt crisis in Mexico in 1994, it became questionable whether Hungary would be able to finance its obligations.

The origins of the crisis had very different roots than in Sweden and lay chiefly in the socialist heritage. Hungary was the country of "goulash communism" where market reforms started as early as 1968. After the revolution in 1956, the socialist leaders aimed at appeasing a hostile population through ensuring higher living standards than elsewhere in the region. The reforms abolished command planning and greatly increased the independence of firms. Welfare services were also expanded and state redistribution increased to 50\% of the GDP in 1968 and to $65.5 \%$ by 1975 , which was by far the highest redistribution rate in the socialist block. ${ }^{52}$ These developments had severe consequences as international economic conditions deteriorated in the 1970s. When demand for the low-quality export products of the socialist firms declined, structural adjustment faced severe constraints: by giving greater independence to these firms the state limited its ability to implement changes against the will of the management. Similar constraints were also present with regard to the extensive welfare provisions, which were seen as necessary for political stability. As a result of these considerations, instead of lowering living standards or adjusting to the new realities the government decided to finance the system by borrowing. ${ }^{53}$ After another wave of borrowing during the mid-1980s for very similar reasons, Hungary started the transition process with a gross debt of $\$ 21$ billion, which was $65 \%$ of the GDP and over $200 \%$ of convertible-currency exports. ${ }^{54}$

The large debt burden of the country made fiscal reforms imperative by 1990. At the same time, this proved to be impossible during the period of the transformational recession: between 1990 and 1993, GDP fell by $20 \%$, while unemploy-

51 Barabás, G./Hamecz, I./Neményi, J.: Fiscal Deficit and Public Debt During the Transition, in: Bokros, L./Dethier, J.-J. (eds.): Public Finance Reform During the Transition: The Experience of Hungary, Washington, DC, 1998, 59-94.

52 Muraközy, L.: Yet Another Change of System: What Can Be Learnt from History and What Cannot, Debrecen, 2004, 17-19.

53 Istvánffy, H. L.: Foreign Debt, Debt Management Policy and Implications for Hungary's Development, in: Europe-Asia Studies, 44/6 (1992), 997-1013, here 997-1000.

54 OECD: Hungary 1991, OECD Economic Surveys, Paris, 1991, 37. 
ment rose from close to zero to over $10 \%$. A number of factors contributed to the depth of the recession. In 1991 Hungary implemented the toughest bankruptcy law in the region, ${ }^{55}$ which led to a wave of bankruptcies and a significant deterioration in the portfolio of the financial sector. The subsequent consolidation of the banking sector meant a large burden for the already vulnerable budget. ${ }^{56}$ The establishment of the institutional independence of the National Bank of Hungary in 1991 and the prohibition of lending to the government put further stress on the budget as the government had to borrow at a much higher interest rate, which greatly increased its debt service burden. The results of these developments became already apparent in 1992, when the budget deficit reached seven percent of the GDP. As the government was unwilling to introduce expenditure cuts and domestic savings were low, the deficit had to be financed through borrowing. This had a negative effect on the current account and led to the appreciation of the exchange rate, which resulted in a serious competitiveness problem and worsened the situation further. ${ }^{57}$

With elections taking place in 1994, the first democratically elected government was unwilling to tackle the problem. After the parliamentary elections, which were won by the socialist opposition, the incoming government postponed adjustment measures until after municipal elections, which took place half a year later. Hungary was approaching a debt crisis.

The collapse was avoided by a surprise stabilisation package implemented by the incoming finance minister, Lajos Bokros, in March $1995 .^{58}$ The package consisted of an immediate devaluation of the currency by nine percent and the introduction of a crawling peg exchange regime with a narrow band of $\pm 2.5 \%$. This policy aimed to boost competitiveness and was meant to produce surprise inflation. As the package also consisted of a wage freeze in the public sector, the

55 The major feature of the new law was that it provided an automatic trigger of bankruptcy through obliging under criminal law any debtor who was in default for more than 90 days to initiate bankruptcy procedures. This was compulsory even when the outstanding debt was small or when the debtor's receivables exceeded his debt. See OECD: Hungary 1993, OECD Economic Surveys, Paris, 1993, 82-83.

56 On the details of the consolidation program see Szapáry, G.: Banking Sector Reform in Hungary: What Have We Learned and What Are the Prospects?, in: Comparative Economic Studies, 44/2 (2002), 103124 , here 107-112.

57 Dethier, J.-J./Orlowski, W.: The Setting: Macroeconomic Policy in Hungary in the 1990s, in: Bokros, L./Dethier, J.-J. (eds.): Public Finance Reform During the Transition: the Experience of Hungary, Washington, DC, 1998, 47-58, here 54.

58 The description of the package relies on Györffy, D.: Governance in a Low-trust Environment: the Difficulties of Fiscal Adjustment in Hungary, in: Europe-Asia Studies, 58/2 (2006), 239-259, here 243245. 
subsequent rise in inflation from $18 \%$ to $28 \%$ led to a sharp decline in real wages (12\% in 1995 and $6 \%$ in 1996). In order to increase fiscal revenues and contribute to competitiveness, the package also imposed an import surcharge of $8 \%$. There were signals about the need to reduce welfare provisions but these together composed only 12 million Hungarian Forint (HUF) from the 170 million package (vs. 70 million HUF from the import surcharge). Efforts were also made to improve the transparency of the budget through decreasing the number of extra-budgetary funds, incorporating quasi-fiscal activities into the budget and setting up a treasury system. ${ }^{59}$ While not officially part of the package, the question of debt reduction was also addressed during the reforms and a strong privatisation drive was started the same year.

The consolidation was successful in averting the debt crisis and avoiding recession. The greatest changes took place in the fiscal balance: from $-8.4 \%$ deficit in 1994, the budget balance improved to $-3.1 \%$ in $1996 .{ }^{60}$ Although internal demand contracted, the strong export performance meant that the growth rate remained positive at $1.5 \%$ in 1995 and $1.3 \%$ in 1996, and then accelerated to over $4 \%$ by $1997 .{ }^{61}$ While the decline in real wages implied a serious stress for the workforce, it also ensured that unemployment did not increase further. The new exchange rate was successful and ensured the credibility of the currency, which is shown by the fact that as long as it was in place, the HUF never left the band. ${ }^{62}$ Finally, public debt was declining fast: from its peak at $90 \%$ of the GDP in 1993, it went to $65 \%$ by $1997 . .^{63}$

The positive developments, however, were not sustainable. After the threat of a collapse was gone, Bokros was forced to resign from his post and the policy of fiscal restraint was slowly abandoned. As a preparation for the next election in 1998, the government increased pensions by $22 \%$ and public sector wages by over $10 \%$. By 1999 , the share of government wage expenditure reached the prepackage level. ${ }^{64}$ The socialists nevertheless lost the elections, and the new cen-

59 László, C.: Vargabetűk az államháztartási reform tízéves történetében [Twists and Turns in the Ten-year History of Public Finance Reforms], in: Közgazdasági Szemle [Hungarian Economic Review], 48/10 (2001), 844-864.

60 Ibid., 846.

61 European Commission, op. cit., 49.

62 Tarafás, I.: Monetary Policy Dilemmas in a Transition Economy: the Case of Hungary, in: Acta Oeconomica, 52/1 (2002), 1-23.

63 László, C., op. cit., 846.

64 Benczés, I.: Institutional Conditions of Expansionary Fiscal Consolidations, PhD thesis, Central European University, Budapest, 2006, 185. 
tre-right government explicitly reversed some of the most controversial elements of the adjustment including the cuts in family allowance, childcare and maternity benefits. The real deterioration of the budget however took place after 2000, when a global slowdown and approaching elections gave strong incentive for the government to overspend. Before the elections, the government doubled the minimum wage and implemented a $30 \%$ wage increase for civil servants. They still lost the 2002 elections to the socialists, who promised even greater benefits. After they assumed power, they fulfilled these promises by abolishing personal income tax for minimum-wage earners as well as implementing a general $50 \%$ wage raise for all public servants. ${ }^{65}$ As a result of these measures, the general government deficit reached $9 \%$ of the GDP. ${ }^{66}$

After the large election and post-election spending, the government was unable to reign in the budget. Efforts to contain wages proved to be ineffective, while the government was unwilling to initiate structural reforms that could contain spending in the long-term. The fiscal balance reflects these developments: deficit remained steadily over $6.5 \%$ since 2002 and reached $9.3 \%$ during the election year in 2006. As a result, the rate of growth declined significantly: in comparison to the other new Central European Member States of the EU, Hungary can expect the slowest growth in $2007-2008 .{ }^{67}$ In sum, a decade after the consolidation, Hungary is facing the necessity of fiscal adjustment again.

\section{Comparing the Politics of Fiscal Adjustment}

As the overview of the two cases shows, Sweden and Hungary followed very different paths in consolidating their public finances and achieved very different results. In accounting for the different choices, the role of political trust will now be analysed through examining three propositions which were generated from the theoretical considerations of the second part of this contribution.

Proposition 1: In a high-trust environment it is easier to reach a consensus on the necessary measures for adjustment because citizens believe that sacrifices in the short-term will produce benefits in long-term.

The consensual nature of fiscal adjustment is one of the most noticeable features of the Swedish reforms. As the crisis erupted, the centre-right government in-

65 OECD: Hungary 2004, OECD Economic Surveys, Paris, 2004.

66 European Commission, op. cit., 177.

67 Ibid., $48 \mathrm{f}$. 
vited the social democratic opposition to agree on the necessary expenditure cuts. The social democrats accepted these cuts under the condition that the major features of the welfare state would remain intact. ${ }^{68}$ They also played a role in the resolution of the banking crisis and participated in the governmental board responsible for the rescue operation. ${ }^{69}$ The general process of implementing longterm measures can be further illustrated by the way the pension system was reformed. As a short-term measure and a way to distribute the social burden of deficit reduction equally, the government and the opposition agreed on a two percentage point reduction of pension benefits in 1992. After a change of government, the social democrats extended this reduction until the budget deficit exceeded SEK 100 billion. In order to solve the long-term sustainability of pension funds, they also initiated the thorough reform of the pension system and implemented it by a consensus among the five major parliamentary parties. ${ }^{70}$

The situation could not have been any more different in Hungary. In spite of the dire economic situation, negotiation of a social pact to handle the crisis failed in 1994. The consolidation package was eventually prepared in secret by six economists without consultation either with the opposition or with the social partners. ${ }^{71}$ For the public, the announcement of the measures came as a shock. The opposition never admitted that the package was needed ${ }^{72}$ and took advantage of the difficult situation of the government. During the next three elections (1998, 2002, 2006), the Bokros package came to play a central role in the conservative campaign to frighten people about the return of the socialists. In a lowtrust environment, such a strategy can be viewed as rational, since an agreement to the measures could have been interpreted as betraying the interests of their voters. The development of trade unions in Hungary provides some evidence for this claim. Although the unions had traditionally close ties to the socialist party, they were informed about the details of the package only three days before its introduction and were thus unable to influence the measures. Still, the lack of a strong protest fatally undermined their credibility and led to a sharp decline in

68 Kato, J./Rothstein, B., op. cit., 85.

69 Svensson, T./Mabuchi, M./Kamikawa, R., op. cit., 49.

70 Anderson, K. M., op. cit., $1078 \mathrm{f}$.

71 Greskovits, B.: Brothers-in-Arms or Rivals in Politics? Top Hungarian Makers in the Hungarian Transformation, in: Kornai, J./Haggard, S./Kaufman, R.R. (eds.): Reforming the State: Fiscal and Welfare Reform in Post-Socialist Countries, Cambridge/New York, 2001, 111-141.

72 Matolcsy, G.: Kiigazítas recesszióval [Stabilisation with Recession], in: Közgazdasagi Szemle [Hungarian Economic Review], 45/9 (1997), 782-798. 
membership, which strongly contributed to the failure of building a socialdemocratic type industrial relation system in Hungary. ${ }^{73}$

The method of implementing fiscal consolidation provides support to the claim that consensus on adjustment is considerably easier to establish and maintain in a high-trust environment. Although elite consensus was the hallmark of Hungarian transition, it broke down in face of the mounting economic difficulties and the widespread disappointment from the transition process. ${ }^{74}$ By the mid-1990s, this made agreement on reforms impossible in accordance with the prediction from the prisoners' dilemma.

Proposition 2: In a high-trust environment, there is greater demand for international best practices than in a low-trust regime because of the room for manoeuvre provided by political consensus.

The presence or lack of consensus about implementing fiscal adjustment strongly influenced the demand for best solutions and provided a different role for experts during the process. In Sweden, long-term measures and institution-building were emphasised during the reforms, while in Hungary the political constraints determined the composition of the package. The main elements of the adjustment were designed to minimise resistance including the devaluation, the subsequent surprise inflation, the import surcharge as well as the acceleration of privatisation. The common feature of these measures is that while they can help to stabilise public finances in the short-term, they do not address the sources of those imbalances and thus do not ensure the sustainability of the adjustment.

The differences in attention to sustainability and in reliance on expert knowledge are well illustrated by the attitudes towards the fiscal management reform. The first paper which established a relationship between the strength of budgetary rules and fiscal outcomes was published in 1992 by Jürgen von Hagen. ${ }^{75}$ The same year, Per Molander, head of the research department in the Swedish Ministry of Finance, undertook an examination of the Swedish budgetary framework based on the research of von Hagen. His report showed that Sweden's budget framework ranked between Greece and Italy, which were the weakest in the

73 Tóth, A.: The Failure of Socialdemocratization of Hungarian Trade Unions, in: Ost, D./Crowley, S. (eds.): Workers after Workers' States: Labor and Politics in Postcommunist Eastern Europe, Boulder, CO, 2002, 64-93, here 79-85.

$74 \mathrm{Agh}, \mathrm{A}$.: Early Consolidation and Performance Crisis: the Majoritarian-Consensus Democracy Debate in Hungary, in: West European Politics, 24/3 (2001), 89-112.

75 Hagen, J. v., op. cit. 
European Union. This finding was very important in ensuring support for modifying the fiscal framework. ${ }^{76}$ The process of reform started almost immediately, and by 1995 a completely new budgeting system was in place. In Hungary, a very different logic prevailed. In spite of the regular warnings by the international financial institutions ${ }^{77}$ as well as the State Audit Office ${ }^{78}$ about the weakness of the budget process, the government was unwilling to implement a stronger fiscal framework and constrain its discretion over spending. This shows that without trust, political constraints strongly dominate decision-making, which lowers the demand for international best-practices even in areas, such as budgetary reforms, which are generally considered as too technical to arouse resistance. $^{79}$

Proposition 3: Fiscal adjustment is more sustainable in a high-trust environment because short-term material benefits are not the only or the primary way to buy political support during elections.

In the second part of the paper it was argued that if citizens do not believe that the system benefits them in the long-run, their support can be bought only through short-term material benefits. It was also emphasised that this holds only if there is a certain degree of fiscal illusion within the electorate. In Hungary, due to the inheritance of goulash communism and state paternalism, fiscal illusion is widespread ${ }^{80}$ At the same time, Swedish citizens are also far from being perfectly informed about the consequences of fiscal policy decisions, as a study of Swedish housing policy illustrates. ${ }^{81}$ This implies that in theory both countries can be subject to populist promises. Figure 2 shows, however that election cycles are only present in Hungary, where election years are always accompanied by a peak in fiscal deficit. In contrast, no similar pattern can be observed in Sweden,

76 Hallerberg, M.: Domestic Budgets in a United Europe: Fiscal Governance from the End of Bretton Woods to EMU, Ithaca, NY/London, 2004, 160-167.

77 Gleich, H.: Budget Institutions and Fiscal Performance in Central and Eastern European Countries, ECB Working Paper no. 215, Frankfurt/M., 2003; OECD: Hungary 2004, op. cit.; IMF: Hungary: 2006 Article IV Consultation, IMF Staff Country Report no. 06/379, Washington, DC, 2006.

78 Állami Számvevöszék [State Audit Office of Hungary]: Jelentés a Magyar Köztársaság 2003. évi költségvetése végrehajtásának ellenőrzéséről [Audit Report on the Implementation of the 2003 Budget in Hungary], Budapest, 2004; idem: A közpénzügyek szabályozásának tézisei [Theses on the Regulation of Public Finances, Budapest, 2007.

79 Molander, P., op. cit., $210 \mathrm{f}$.

80 Csontos, L./Kornai, J./Tóth. I. G.: Tax Awareness and Reform of the Welfare State: Hungarian Survey Results, in: Economics of Transition, 6/2 (1998), 287-312.

81 Lindbom, A.: Dismantling Swedish Housing Policy, in: Governance, 14/4 (2001), 503-526. 
where the fiscal balance improved steadily between 1993 and 2000 and started to deteriorate somewhat afterwards reaching its lowest level during the 2002 election year. It is very likely, however, that this deterioration was more due to the international economic slowdown than to the elections, which can be supported by the fact that the deficit was nowhere near to the Hungarian level, where elections were held the same year.

Overall, the cases of Sweden and Hungary shed light on the very different constraints policy-makers face in implementing fiscal adjustment in a high-trust and a low-trust environment. In a high-trust regime, first-best solutions can be implemented by political consensus. In a low-trust regime, the need to continuously buy the support of the electorate makes consensus on reforms impossible, thus strongly constraining the composition of the package. This difference is reflected in the success of the adjustment: while the consolidation proved to be lasting in Sweden even after the crisis was over, once the threat was averted, fiscal policy was loosened in Hungary. The next section will consider the potential for generalising these experiences in explaining the differences of fiscal performance within the EMU.

Figure 2: Elections and Fiscal Balance in Sweden and Hungary (\% GDP)

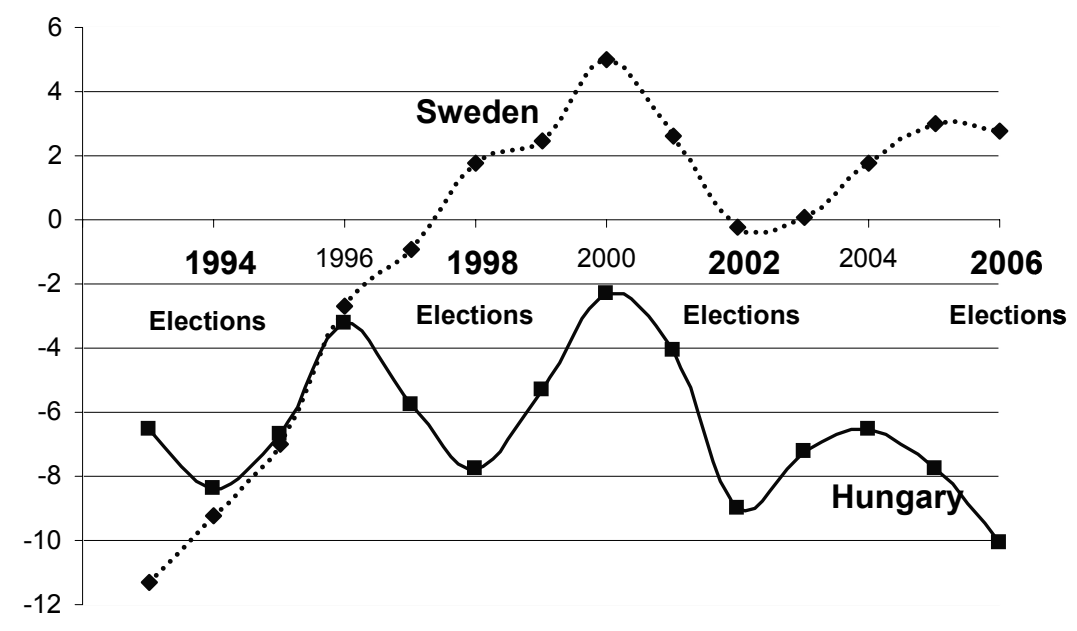

Source: Author's compilation using data from European Commission, op. cit., 177 and László, C., op. cit., 846. 


\section{The Experiences of EMU Countries 1993-2005}

The experiences of EMU countries present a unique opportunity to consider the potential for generalising the experiences of Sweden and Hungary. The present members of the EMU (with the exception of Slovenia, which joined in 2007) all consolidated their public finances during the Maastricht convergence process between 1993 and 1997. In every member state, there was a strong pressure to reduce the fiscal deficit below the required $3 \%$ of the GDP. ${ }^{82}$

The eventual introduction of the common currency provided a new environment for fiscal policy. The Stability and Growth Pact, which was designed to ensure discipline after the qualification period was over, proved to be ineffective: in spite of its regular breach by EMU countries, no fine was ever imposed on the trespassers. ${ }^{83}$ At the same time, credibility of the Euro was strongly established on the international financial markets, which is shown by the steady decline and convergence of interest rates (Figure 3).

Figure 3: Yield Spread for Ten-year Government Bonds Relative to Germany

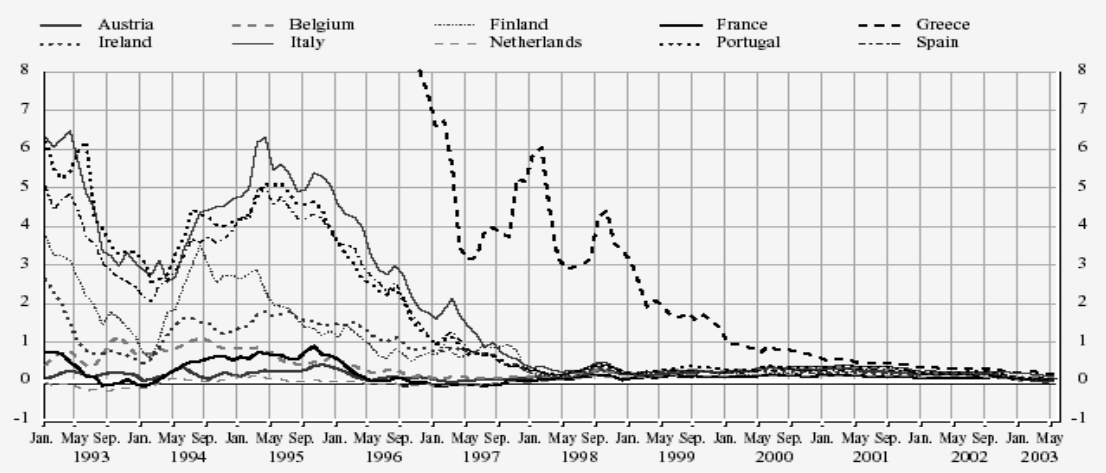

Source: Baele, L. et al.: Measuring Financial Integration in the Euro Area, European Central Bank Occasional Paper no. 14, 2004, 37.

82 Hallerberg, M., op. cit.

83 The ineffectiveness of the Pact has given rise to a considerable literature. For an extensive survey of this literature see Fischer, J./Jonung, L./Larch, M.: 101 Proposals to Reform the Stability and Growth Pact. Why So Many? A Survey, European Economy - Economic Papers no. 267, Brussels, 2007. 
The above mentioned developments imply that in the EMU Member States there was only a moderate external pressure either from European regulations or the international financial markets to conduct responsible fiscal policy. Under such circumstances it is reasonable to assume that the maintenance of fiscal restraint was primarily determined by domestic factors. Consequently, the period since 1998 provides an excellent opportunity to examine the effects of trust on fiscal discipline.

In order to approximate the level of political trust, the results of Eurobarometer surveys on satisfaction with democracy will be used. While this is not a perfect measure of political trust, it does capture an important element of the definition which was used in this paper for trust - the belief that the system produces good outcomes. Although this indicator is slightly sensitive to shocks in everyday politics, taking an eight-year year average can smooth out some of the temporary effects. Taking a longer-term average is also useful with regard to fiscal deficits since it helps to smooth out the effects of the economic cycle, which can have a significant influence on the level of deficit. Figure 4 shows the relationship between the average level of satisfaction and net lending.

Figure 4: Satisfaction with Democracy and Fiscal Outcomes in the EMU 19982005

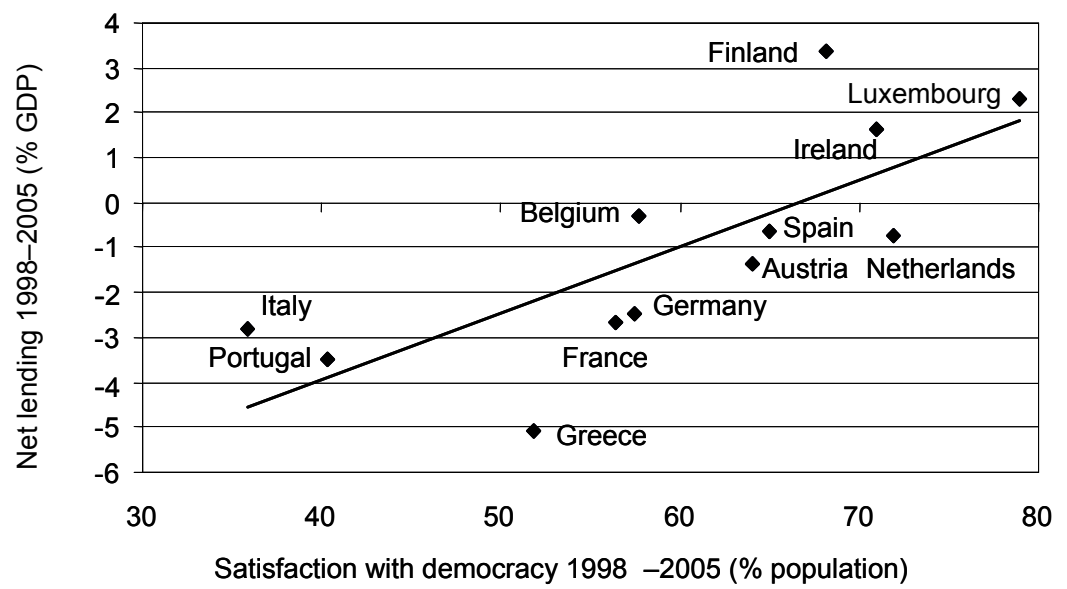

Net lending $=0.148$. Satisfaction $=-9.875$. R-square $=0.568$. The level of satisfaction indicates the share of population who is either "very satisfied" or "fairly satisfied" with the way democracy works in her country.

Source: Author's compilation using data from Eurobarometer nos. 49, 51, 53, 56, 58, 59, 61 and 63 as well as from European Commission, op. cit., 176. 
In line with the hypothesis derived from the theory and the experiences of Sweden and Hungary, a strong correlation can be observed between satisfaction and fiscal balance during 1998 and 2005. Naturally, given the small number of observations and the short time period these numbers have to be treated carefully. In order to establish the relationship conclusively, further research is needed, including more countries and longer time periods. At the same time, the strong correlation between the two variables provides support for the potential to generalise the lessons from the Swedish and the Hungarian cases.

\section{Conclusions}

The original puzzle of this article was that in spite of a strong pressure from the global financial markets to maintain balanced public finances, there is still considerable divergence in fiscal outcomes in small open economies. Based on the experiences of Sweden and Hungary, it was shown that fiscal adjustment is a form of social dilemma which can be resolved successfully only if there is a sufficient level of trust in the system. While the different levels of trust in the two countries did not preclude consolidation under strong external pressure, it had a strong influence on the composition of the adjustment and its implementation. This difference in turn determined the sustainability of measures after the crisis was over. Limited evidence indicates that similar developments can be observed in the EMU member states as well.

The results have important practical relevance for emerging economies, which are generally characterised by a low level of political trust and struggle with the challenge of fiscal consolidation. In these countries, the sustainability of public finances is a high priority, which however cannot be separated from the broader issue of institutional quality. Building trust in the system thus needs to accompany fiscal consolidation in order to achieve lasting success. Neglecting such measures can easily lead to a strong deterioration of political trust during the adjustment and result in a downward spiral of distrust, economic populism and slow growth. This consideration might be particularly important for the new Member States of the European Union, which will face considerably less external pressure for responsible fiscal policy after they introduce the common currency than other emerging economies. 
The main implication of the research is that trust is a major factor in the ability for self-correction. ${ }^{84}$ It conditions a country's potential for adapting to the global environment which in turn allows enjoying the potential benefits while avoiding the dangers. The bad news about this finding is that the process of adaptation is considerably more challenging than mainstream economics and the international financial institutions generally suggest. The good news, however, is that the requirements for political and economic development presuppose rather than contradict one another.

84 On the importance of self-correction in complex systems see Csaba, L.: The New Political Economy of Emerging Europe, Budapest, 2005, 343-348. 